effectively revitalize rivers as compelling subjects for historians. They also succeed in resisting the declensionist narrative that has become so predictable in environmental history, taking care to highlight how change brought unexpected consequences and "environmental surprises" — and not always for the worst. At times species diversity, for example, increased in particular places at the expense of others. Irrigation projects resulted in the creation of beaver and muskrat habitat — developments which brought their own challenges for prairie farmerswhile dam construction created conditions that favoured some species and decimated others.

My criticisms are minor. On the whole, the three authors achieve a remarkable consistency of tone and writing style throughout. This slips somewhat in chapters 10 through 12, which, perhaps due to the complexity of the diverse constituencies and jurisdictional authorities that they cover, lose some of the lyricism and elegance of construction so notable in preceding chapters. Early in the book the authors introduce the idea of the river as an archive, reflective of William J. Turkel's notion of the "archive of place" forwarded in his 2007 history of British Columbia's Chilcotin Plateau. Rivers, however, are as much forces of erosion and erasure as catalogues of past uses and decisions. The tensions within this analogy could have been more fully explored, and elaborated upon more consistently through the text. The book concludes by looking ahead to sources of conflict in the future, mobilizing the river's past to generate potential insights for public policy. Chief among these concerns is the very real threat of water scarcity as a result of global warming. The authors speculate upon what kind of place the Bow basin will become, and how such changes will affect the different uses and users of river discussed in the book. I found myself wanting to know more about this largest of issues facing the Bow in the years to come. Perhaps this was the authors' intent.

Jennifer Bonnell

University of Toronto

\title{
Jean-Francois Constant and Michel Ducharme, eds., Liberalism and Hegemony: Debating the Canadian Liberal Revolution (Toronto: University of Toronto Press, 2009).
}

Jean-Francois Constant and Michel Ducharme are to be heartily commended for bringing together such a wide range of stimulating and highly sophisticated articles which together challenge, test and revise Ian McKay's original liberal order reconnaissance. Unlike the majority of collected works which usually contain but a handful of first-rate articles, Liberalism and Hegemony contains such a critical mass of thoughtful articles which display a great command of theoretical and empirical perspectives, that I would recommend that it become a benchmark text 
for all doctoral students and Canadian historians.

Much of the importance of this volume rests with the editors themselves whose introduction is balanced in showing how McKay's initial proposition remains innovative not necessarily because it offers a particular framework, but because it has generated a wide range of historical debate which has shifted the preoccupations of Canadian historians beyond the social history/political history divide. They are, however, more sceptical of McKay's version of the liberal order which posits liberalism as a "totalizing philosophy," as well as its overemphasis upon individual property rights as fundamental to this liberal order which Constant and Ducharme believe weakens the innovativeness of McKay's reconnaissance because it replays the older political-economic paradigms (combining the event history of an Arthur Lower within a neo-Marxist theoretical frame). Given their interests, the editors are at their best when they show the limitations of McKay's framework, which for the most part ignores Quebec, and in particular, it ignores the important contributions of Jean-Marie Fecteau which has, along with the work of Nancy Christie and Michael Gauvreau, clearly demonstrated that religion and the institutional church was just as, if not more important, than the state in shaping the liberal order. More particularly, Constant and Ducharme reaffirm the 1840s as a critical juncture in the emergence of the liberal order and while they later question the end point of McKay's periodiziation in the 1940s, I think that given the importance of Jerry Bannister's emphasis on the counterrevolution and its liberal tendencies (which reverses Hartz's thesis of liberalism with a Tory touch) that the editors might have been prompted to also uncover the liberal-republican ideological complexity of the rebellions in order to query why 1840 should be taken as a starting point. If the liberal order framework is in fact a means to study the theoretical political aims of the project of rule, why limit this project to the period following the failed rebellions of 1837-38? As Bannister rightly states "liberalism itself cannot be understood as an elemental or inviolable force that suddenly emerged ex-nihilo, in the mid-nineteenth century" (100). What Constant and Ducharme's introduction makes clear, is that there are in fact two liberal projects at work within McKay's framework: one which concerns the timing and emergence of liberal (often with slippage to Liberal) political ideas and a Gramscian project which concerns issues of hegemony. As they suggest, it is this Gramscian neoMarxist ideology that makes McKay's reconnaissance a distinctly political project and that in the end renders it less useful as an historical concept.

In a book full of stimulating articles, those by McNairn and Curtis were particularly hard-hitting in exposing the theoretical limitations and distortions inherent in McKay's foray. McNairn is in full control of his subject when exposing the selective nature of McKay's concept of liberalism founded upon the priority given to the individual, and its relationship to property, equality and liberty. Essentially McNairn is arguing for greater historicism, of properly situating liber- 
al ideals (and their uses) in their historical context, and, in an argument that is similar to that articulated by Robert McDonald, McNairn shows how variegated liberalism was and how those espousing liberal ideas could challenge other aspects of liberalism. McNairn, McDonald, and Robin Brownlie, whose focus is upon aboriginal peoples, all show how those nominally excluded from the liberal order according to McKay also used the liberal order to argue for rights. In this way women and aboriginal peoples are both excluded from, and at the same time use, liberal ideas to construct their own rights talk and identities within the liberal order. Certainly the essays by Brownlie, McNairn, and McDonald prompt us to construct more nuanced conceptual frameworks which avoid reducing the liberal order to a neo-Marxist critique of "bourgeois values or market relations." (75). Like McNairn, Curtis, in a tour de force of theoretical exposition, maintains that McKay's framework is overly economic in its focus and far too state driven, and that his preoccupation with Gramsci's theories creates a liberal order which is reduced to two sides of one polarity: hegemony and resistance whose players are the dominant and subaltern groups. With great clarity and intellectual rigour, Curtis has set out to elaborate a framework which focuses on "a liberal mode of government", extrapolating from the notion of governmentality set forth by Michel Foucault. This is of great value because it avoids the state-civil society binary and because by seriously addressing the notion of discourse in a way not pursued by McKay, Curtis is able to show how liberal theorists actually set out to "colonize individual subjectivities". Curtis' framework has much to recommend it: it asks historians to be specific about what liberal project they are talking about, it shows how liberalism and its individualist ethos cannot be divorced from the social, and it clearly demonstrates how the liberal project succeeds by acting through various sites which include the family, voluntary organizations and the state to create self-governing individuals. Curtis's theoretical proposition also possesses the great advantage of avoiding an over-emphasis on the "big events" of traditional political history which framed McKay's chronology. Whether you are an admirer of Foucault or not, Curtis' contribution to this volume carries great intellectual force not least because it shows why one project of rule is far too limiting a construct and it offers an approach which is less top down and which gives due attention to discourse and sites of power outside the state.

Liberalism and Hegemony is an extremely important volume which should become a staple on all comprehensive lists for emerging Canadian historians. There are some absences in this volume: an article on the rule of law (a component deemed pivotal in any conceptualization of the liberal order as Constant and Ducharme note) would have been welcome, as would an article which focused on the post 1940 period, and a consideration of the sphere of civic and associational life. However, this is mere cavilling, as this volume packs a powerful intellectual punch, so much so that I think the revisions offered by all the 
contributors have now largely displaced the original enunciation of the thesis, and that perhaps there is no one key to all mythologies as George Eliot's Mr. Casaubon would have it.

Nancy Christie

University of Western Ontario

Christopher Dummitt and Michael Dawson, eds., Contesting Clio's Craft: New Directions and Debates in Canadian History (London: Institute for the Study of the Americas, 2009).

As one of only a few essay collections since the publication of Carl Berger's Contemporary Approaches to Canadian History (1987) to claim to bring together "new" directions and debates in Canadian history, this volume marks an important milestone in Clio's craft. Berger concluded The Writing of Canadian History (1986) with the warning that Clio has "an alarming habit" of devouring those who follow her charms (320). Although young historians may well build upon the work of their predecessors, he implies, they are reluctant to admit doing so, preferring to emphasize their break with the tired approaches of their deluded mentors. It is instructive, then, to reflect on what a new generation of historians understands as cannibalism.

Unlike Berger's volume, which reprinted review articles on "the new history" in such sub-fields as ethnic, regional, women's, and working class history, this collection of essays emerged from a single conference, convened at the University of London in 2007. Those invited to present papers were junior scholars identified as charting new directions in theory and methodology. In addition to the editors, the essayists published in this volume include Michel Ducharme, Catherine Gidney, Stephen High, Adele Perry, Katie Pickles, and Andrew Smith. Instead of offering overviews of emerging sub-fields, the articles, we are told by the editors in the introduction, are meant to encourage debates that move beyond dated discussions about the failure of Canadians to know their own history; the role of social history in undermining the national narrative; and the nature of historical knowledge and claims to truth. While few academic historians would disagree with the need for more substantive debates on the form, content, and import of Canadian history, it is unclear from most of these essays what needs to be debated. The trends in historical inquiry promoted here - transnational, comparative, post-colonial, public/oral, narrative, and Atlantic world — to amend practices of earlier unworthies are timely suggestions and unlikely to generate much debate. Surely, such approaches co-exist comfortably with national and social understandings of the past, neither of which can or should be abandoned. Although the editors suggest that there are divisions among the authors of this volume on whether the attempt to write a 